\title{
BIOACTIVE AND FUNCTIONAL PROPERTIES OF FISH PROTEIN HYDROLYSATE FROM LEIOGNATHUS BINDUS
}

\author{
JOHNROSE PRABHA ${ }^{1 *}$, SAVARIAR VINCENT ${ }^{1}$, SWAPNA JOSEPH ${ }^{2}$, JOACY MAGDALENE ${ }^{2}$ \\ ${ }^{1}$ Centre for Environmental Research and Development, LIFE Loyola College, Chennai, Tamil Nadu, India. ${ }^{2}$ P.G. Research \& Department of \\ Advanced Zoology and Biotechnology, Loyola College, Nungambakkam, Chennai, Tamil Nadu, India. Email: prafas@gmail.com
}

Received: 09 July 2016, Revised and Accepted: 14 July 2016

\section{ABSTRACT}

Objective: The present work is focused on the production of biologically active protein hydrolysate from low value by-catch fish, Leiognathus bindus; this will be an ideal approach to exploit the underutilized fish to develop a highly nutritious bioactive product. Moreover, fish protein hydrolysates have a broad spectrum of applications ranging from high-value peptones to food ingredients with special functional properties.

Methods: The protein hydrolysate was prepared from L. bindus through acidic autolysis processes. The proximate composition, physico-functional, and biochemical properties of hydrolysate and control samples were characterized by standard protocols. Molecular profiling was done by sodium dodecyl sulfate polyacrylamide gel electrophoresis and high-performance liquid chromatography analysis performed to identify the essential amino acid composition in protein hydrolysate.

Results: The results of this study reveals that the protein hydrolysate obtained from the trash fish has relatively high protein $(71.01 \pm 0.2 \%)$ and low lipid $(1.57 \pm 0.1 \%)$ content. The molecular analysis shows low molecular weight peptides are obtained in the hydrolyzed samples which indicate high protein solubility confirmed to have the potential application as an ingredient in the balanced human diet. The chemical score of the hydrolysate indicates that it fulfills adult human nutritional requirements.

Conclusion: This approach also offers the relatively simple and cost-effective process to improve the nutritional characteristics and functional properties of foodstuff, also an opportunity for the conversion of waste fish resources to nutritious products, that can be used in food and pharmaceutical industries.

Keywords: Protein hydrolysate, Emulsifying property, Bioactive, Peptides, Amino acid, Chemical score.

(C) 2016 The Authors. Published by Innovare Academic Sciences Pvt Ltd. This is an open access article under the CC BY license (http://creativecommons. org/licenses/by/4. 0/) DOI: http://dx.doi.org/10.22159/ajpcr.2016.v9i5.14002

\section{INTRODUCTION}

Fish protein is an essential source of nutrients for many people, especially in developing countries. Fisheries generate renewable natural resource and subject to its own dynamics. Among the various commercial industries, the fisheries occupy a major place in promoting the socioeconomic development of the country. However in worldwide, it was noted that about $25 \%$ of the total resource had been wasted in the fishing industry [1]. Moreover, about 38.5 million tons of species of the global marine fish captures are known to be by-catch and discarded due to low market value $[2,3]$.

By-catch is part of fishery catch which may be retained and landed but is usually discarded or released back to the sea in dead or alive. By-catch is a rich bioactive resource with potential application in industries such as pharmaceuticals, food and diet, animal nutrition, and cosmetics [4]. Therefore, a basic understanding of these components is essential to develop new technologies with high yields so that the processing can be economically sustainable [5]. Leiognathus bindus are generally considered as important bycatch owing to much less fat content and bones rich in calcium, making them commercially valuable especially for food industries. The fish tissue is known to have increased nutritional significance thereby, can be a valuable dietary module [6]. The preparation of the protein rich hydrolysate from the by-catch fish also serves as a solution for the environmental pollution due to the accumulation of fish waste and utilization of raw material [7].

Protein hydrolysates can be obtained by the hydrolysis process in which the protein is broken down by protease enzymes. Hydrolysis can decrease the peptide size and convert the hydrolysates to obtainable amino acid resource for protein biosynthesis [8]. Fish protein hydrolysates (FPHs) have predictable functional properties. An increase in the number of peptide molecules and exposed hydrophobic amino acid residues due to hydrolysis of proteins would contribute to the formation of emulsions [9]. Protein hydrolysates generated from fish proteins are good nutritional supplements as bioactive compounds [7] and can be easily absorbed and utilized for various metabolic activities.

From the previous studies, it is evident that the L. bindus rich source of protein used for the preparation of nutritious rich health mix powder [10]. However, there have been no reports available in studying the production of potentially bioactive FPH with from $L$. bindus. There exists a need to explore the possibility of developing valuable products from trash fish for the better utilization of these nutritious resources. Hence, this study is focused on the production of FPH from $L$. bindus through novel hydrolysis process and to characterize the biochemical and physico-functional parameters of the FPH.

\section{METHODS}

\section{Collection of samples}

The fish samples, L. bindus, are identified and were collected from Royapuram, the main fish landing stations in the southern coastal region of Chennai, Tamil Nadu, India. The samples were collected in icecold conditions and immediately brought to the laboratory for further analysis. The samples were stored in sterile conditions at ice-cold temperature.

\section{Physical analysis and sample preparation}

The samples were collected in ice-cold condition and subjected to physical analysis to understand the freshness of the sample. After analysis of physical condition to evaluate the freshness, the fish samples were rinsed and filleted down. The fillets were packed in polyethylene bags and freeze-stored at $-20^{\circ} \mathrm{C}$ until used. The homogenate was 
obtained from mincing filleted tissues with water (in the ratio of 1:3) using high-speed blender for 2 minutes and preserved at $-20^{\circ} \mathrm{C}$ until further analysis.

\section{Preparation of FPH}

The frozen homogenate was thawed and then divided into batches for the preparation of hydrolysate for the preliminary studies in order understand the range of temperature and the $\mathrm{pH}$ to be maintained in optimum hydrolyzing condition. The acidic condition was maintained in the presence of sulfuric acid:formic acid. The $\mathrm{pH}$ values ranging from 2 to $7 \mathrm{pH}$ were adjusted, and the autolysis was carried out by maintaining a temperature range of $30-60^{\circ} \mathrm{C}$ in shaker incubator and samples were withdrawn at a different time interval (0-120 minutes). The hydrolysate was heated to terminate the endogenous enzyme activity and centrifuged at $6500 \mathrm{rpm}$ (revolutions per minute) for 15 minutes to obtain the supernatant and was then freeze-dried and characterized.

\section{Biochemical methods}

\section{Proximate composition and degree of hydrolysis (DH)}

The total crude protein, total lipid, ash, and moisture in raw materials were determined according to AOAC [11]. DH was defined as the proportion of cleaved peptide bonds in a protein hydrolysate [7]. DH was computed as:

$\% \mathrm{DH}=[10 \%$ TCA soluble N2 in the sample/Total N2 in the sample $] \times 100$

\section{Protease enzyme assay - (tyrosine standard method)}

The proteolytic activities of the crude protein extract were determined based on the casein hydrolysis assay of Kunitz [12] as modified by Walter [13], where Casein was used as a substrate and tyrosine taken as standard to construct the standard curve. One unit of specific activity was defined as the amount of enzyme needed to produce $1 \mu \mathrm{g}$ tyrosine per minutes per mg soluble protein of enzyme extract (U mg/protein).

\section{Foaming capacity}

Foaming capacity was determined by slight modification in the method of Coffman and Garcia [14]. A known quantity of the hydrolyzed sample was mixed with $100 \mathrm{ml}$ of distilled water. The initial volume of the sample is measured and stirred for 10 minutes using a mechanical stirrer. The final volume along with foam formed is measured. The difference of the final volume and the initial volume is the foaming capacity and foaming stability is the volume measured at time intervals of $5,10,20,30,40$, and 60 minutes. Foaming capacity is expressed in percentage (\%).

Foaming property $=\frac{\begin{array}{l}\text { Final volumeafter whipping } \\ \text { Initial volumeof the sample before whipping }\end{array}}{\text { - }}$.

\section{Emulsifying capacity and stability}

Emulsion was determined by slightly modified method of Beuchat [15] procedure. $1 \mathrm{~g}$ of protein hydrolysate was blended at in high speed in blender with deionized water for 60 seconds and vegetable oil was added in $5 \mathrm{ml}$ portions through continuing to blending. The emulsion so prepared was then allowed to stand in a graduated cylinder, and the volume of water separated in separation phase was observed. EC is expressed as milliliter of oil emulsified per gram of hydrolysate.

\section{Emulsifying property $=\frac{\text { Volumeof oil released }- \text { Volumeof oil released }}{\text { Weight of thesample }}$}

Molecular analysis using sodium dodecyl sulfate polyacrylamide gel electrophoresis (SDS-PAGE)

Molecular weight distribution of hydrolysates SDS-PAGE was carried out according to the method of Laemmli [16], using a $4 \%$ stacking gel and a $12 \%$ separating gel. Hydrolysate samples $(1 \mu \mathrm{g} / \mu \mathrm{l})$ were mixed $1: 1(\mathrm{v} / \mathrm{v})$ rationally with the sample buffer $(0.5 \mathrm{M}$ Tris- $\mathrm{HCl}, \mathrm{pH} 6.8)$ and heated for 2 minutes before loading. A standard wide range marker of 10-200 kDa (purchased from Sigma-Aldrich) was used for the determination of molecular weight.

\section{Amino acid composition}

Hydrolyzed samples derivatized using phenyl isothiocyanate precede to high-performance liquid chromatography (HPLC) analysis. The total amino acids were determined by HPLC using a C18 column at the flow rate of $0.5 \mathrm{ml} /$ minute with $338 \mathrm{~nm}$ Wavelength of detection (VWD) and reaction temperature of $40^{\circ} \mathrm{C}$.

\section{Chemical score}

The chemical score of the prepared protein hydrolysate sample was computed according to Ovissipour [17]. It was calculated relative to the essential amino acid (EAA) profile in a standard reference protein as described by FAO/WHO [18] and NRC [19]. Briefly, the chemical score was calculated based on the following equation:

Chemical score $=\frac{\text { EAAinsampleprotein }\left(\frac{\mathrm{g}}{100 \mathrm{~g}}\right)}{\text { EAAinstandardreferenceprotein }\left(\frac{\mathrm{g}}{100 \mathrm{~g}}\right)} \times 100 \%$

\section{Statistical analysis}

The data obtained were subjected to one-way analysis of variance using SPSS 12 the statistical software. Duncan's new multiple range test was performed to determine the significant differences between samples at the $5 \%$ probability level.

\section{RESULTS AND DISCUSSION}

The protein hydrolysate obtained is a complex mixture of peptides of different chain length together with free amino acids. Autolytic method is also reported for the recovery of proteins from underutilized fish [20] or fish processing waste [21]. However, a few studies [22] have shown hydrolysate could be obtained through autolysis with comparable yield. Moreover, due to the simplicity of the operation and no enzyme costs involved the process is still used for the preparation of protein hydrolysate.

In this study, proximate composition of unhydrolyzed raw material and hydrolysate protein prepared in autolysis process is shown in Table 1. From the results, it was evident that the protein content of FPH is high $(71.1 \%)$, whereas in unhydrolyzed sample, the percent of protein content was comparatively low, i.e., $49.0 \pm 0.3 \%$. The results coincide the results of previous studies where the protein content ranged from $63.4 \%$ to $89 \%$ [20,23-26]. In contrary to protein content, the lipid level exhibits a converse range in hydrolyzed sample $(1.57 \pm 0.1 \%)$ when compared to unhydrolyzed $(27.4 \pm 01 \%)$ raw sample mainly due to the interference of acid hydrolysis. In acidic hydrolysis, free lipids cross-linked to proteins and as well break-up protein particles so that most lipids are accessible to solvent. As reported earlier $[23,27]$, the reduction in lipid content in FPH in the present may be due to the exclusion in centrifugation and mostly due to lipid oxidation, However, the elimination of lipid can improve the stability and quality FPH product.

Table 1: Proximate composition $(\% / \mathrm{ml})$ of control and $\mathrm{FPH}^{\mathrm{a}}$ samples

\begin{tabular}{lll}
\hline Composition (\%) & Contol & FPH \\
\hline Protein & $49.0 \pm 0.3$ & $71.0 \pm 0.2$ \\
Lipid & $27.4 \pm 0.1$ & $1.57 \pm 0.1$ \\
Moisture & $10.7 \pm 0.1$ & $4.76 \pm 0.02$ \\
Ash & $12.8 \pm 0.1$ & $22.65 \pm 0.1$ \\
\hline
\end{tabular}

${ }^{a}$ Values represented mean \pm SE $(n=3)$. FSH: Fish protein hydrolysate,

SE: Standard error 
Protein recovery

The results of protein recovery obtained by different $\mathrm{pH}$ and time are presented in Fig. 1. There was a significant difference $(\mathrm{p}<0.05)$ in protein recovery was noted among the different hydrolyzing conditions. From the results, it is evidence of the concentration of protein increase with an increase in time and gradually reduced after the optimum condition. For instance, the concentration of protein at $\mathrm{pH} 4$ is $60.68 \pm 0.3 \mu \mathrm{g} / \mu \mathrm{l}$ at 60 minutes, whereas at 90 minutes, it increases to $63.60 \pm 0.9 \mu \mathrm{g} / \mu \mathrm{l}$. In hydrolysates high protein recovery ranged from $63 \%$ to $71 \%$ and has been increased with increasing incubation time, similar trend was also reported by Nemati et al. [25], Ovissipour et al. [28]. It is due to the ionic strength or hydrophobicity and also indicates that maximum peptide bonds are broken, and free amino acids are released.

\section{DH}

According to Souissi [29], DH increase with an increase in hydrolysis time and correlates with $\mathrm{pH}$ in reaction mixture. In this study, the $\mathrm{DH}$ exhibits a bell-shaped pattern and the related result was also reported by Souissi et al. [29], Amiza et al. [30]in silver catfish frame hydrolysis. The effect of $\mathrm{pH}$ and time on DH is normally in bell-shaped pattern with increases in steady state at 90 minutes in $\mathrm{pH}$ (2-7) is clearly shown in Fig. 2. In contrast, at 120 minutes declining status in DH is due to higher $\mathrm{DH}$, due to a maximum rate of peptide cleavage [28]. The values of DH in may be useful in preparing hydrolysates with certain functional properties, since the DH is the principle determinant of protein hydrolysate properties. The result was in accordance to [28] in which DH of yellow tuna fish increased with increase in hydrolysis time.

\section{Protease activity}

During hydrolysis, the fish tissue is degraded by endogenous and exogenous protease enzymes and these enzymes hydrolyze protein into smaller peptide units or free amino acids. According to Barrett [31], protease is proteolytic enzymes which are a group of enzymes whose catalytic function was to hydrolyze proteins. From the Fig. 3, it was evidence the protease activity increase at the time interval of 90 minutes. However, the hydrolysis of the fish was characterized by an initial rapid phase, during which a large number of peptide bonds were hydrolyzed. The protease activity red sea bream Pagrus major [32] and Takifugu obscurus [33] also initiate hydrolysis of the intact protein as it was observed in the present study.

\section{Foaming capacity and emulsifying property}

The foaming capacity of protein hydrolysate showed a significant difference in different $\mathrm{pH}$. A good foaming capacity might attribute to an increase in the surface activity, which is due to partial proteolysis that produced the greatest number of polypeptide chains and therefore allowed more air to be incorporated. The protein hydrolysate obtained in the present study prepared at $\mathrm{pH} 5$ gave highest high foaming capacity. The foaming capacity is improved on limited proteolysis. DH had a higher whippability, which was even better than the undigested protein. Foam formation decreased with increasing DH and also with increasing $\mathrm{pH}$ values and related to the result reported by Amiza et al. [30] (Fig. 4).

Environmental conditions such as $\mathrm{pH}$, ionic strength, and temperature have an effect on the emulsification properties. It was found that the emulsion capacity is optimized when the protein had a balance between hydrophilic and hydrophobic residues [34]. In this study, the high range of emulsifying capacity was observed at pH 5 at 60 minutes and $57.14 \%$ and decline rate at 90 minutes. There are many different factors that may account for the difference observed between hydrolysates in both the ability to form an emulsion and emulsion stability, such as peptide molecular characteristics and peptide chain length show the major impact [23] (Fig. 5).

\section{Molecular profile}

The molecular profile of the samples has been notified through SDS-PAGE, and the results show that the samples have a low molecular weight. The banding pattern in L2 and L3 lane indicate that the samples possess low molecular weight protein as the bands coincides with

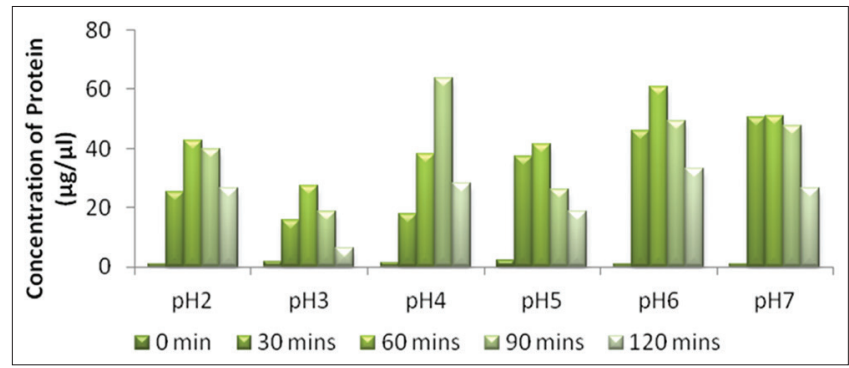

Fig. 1: Results for protein content $(\mathrm{mg} / \mathrm{ml})$ in Leiognathus bindus fish protein hydrolysate prepared at different condition

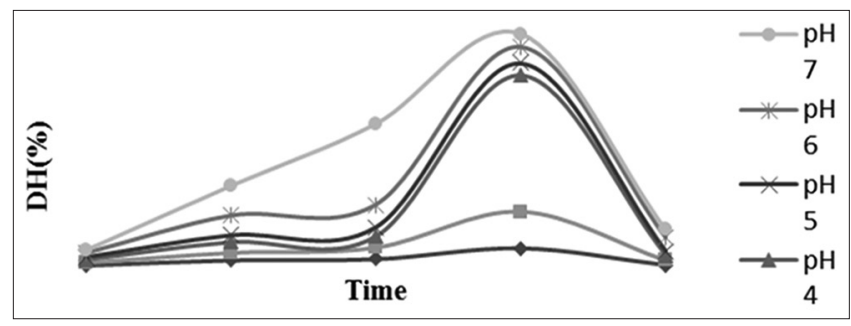

Fig. 2: Degree of hydrolysis $(\% / \mathrm{ml})$ in Leiognathus bindus fish protein hydrolysate prepared at different hydrolyzing condition (time and temperature)

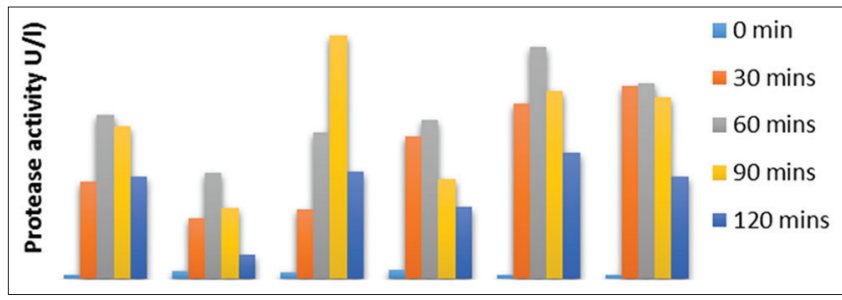

Fig. 3: Protease activity (U/1) in fish protein hydrolysate from Leiognathus bindus in different hydrolyzing condition

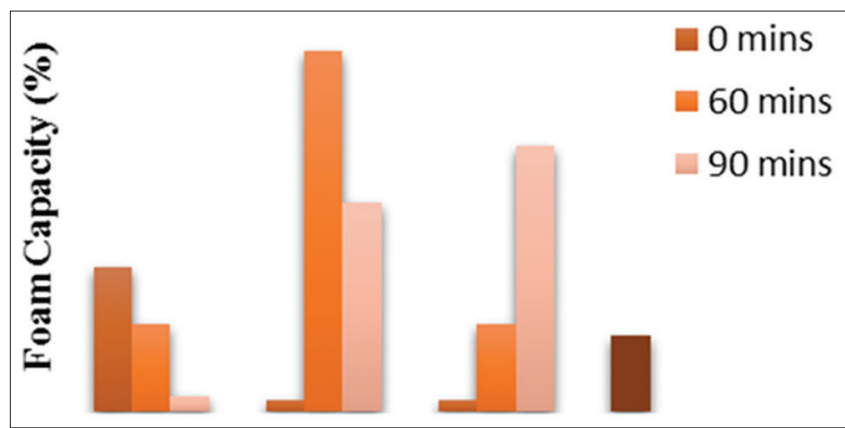

Fig. 4: Foaming capacity $(\% / \mathrm{ml})$ in Leiognathus bindus fish protein hydrolysate in different $\mathrm{pH}$ and time interval

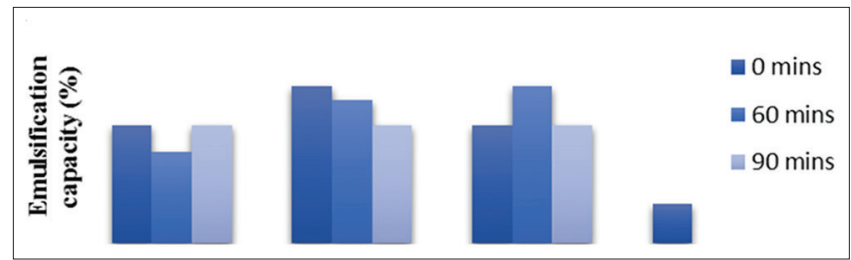

Fig. 5: Emulsification capacity $(\% / \mathrm{ml})$ in Leiognathus bindus fish protein hydrolysate and control samples

$6^{\text {th }}$ to $7^{\text {th }}$ bands of the marker. This indicates the molecular weight of the samples lie in the range of $14-20 \mathrm{kDa}$ due to the extent of protein 
hydrolysis was supported by the disappearance of large proteins in the electrophoretic profile of the protein hydrolysates (Fig. 6). The low molecular weight peptides in the protein hydrolysates indicating the efficacy of these protein hydrolysates as a source of bioactive peptides[24]. The recovery of protein was very high thus, making it a soluble peptide.

\section{Amino acid composition}

In this study, there was significant $(\mathrm{p}<0.05)$ result for EAA. It was observed that hydrolysates sample has EAA threonine, methionine, isoleucine, lysine, and phenylalanine; this indicates the hydrolysate is nutritionally rich products shown in Table 2 and Fig. 7. Indeed, protein hydrolyzates developed by acid analysis were rich EAA, which includes leucine, arginine, histidine and lysine, but lower in tyrosine, aspartic acid and alanineh as compared to fish muscle. This finding was close to the report of Klompong et al. [6] which showed that yellow stripe trevally (Selaroides leptolepis) protein hydrolysates had a higher ratio of EAAs to non-EAAs compared to unhydrolyzed flesh. Shahidi et al. [20] also reported autolytic method can be suggested for recovery of proteins either from underutilized or fish processing waste. However, some studies [35] have shown hydrolysate could be obtained through autolysis with comparable yield.

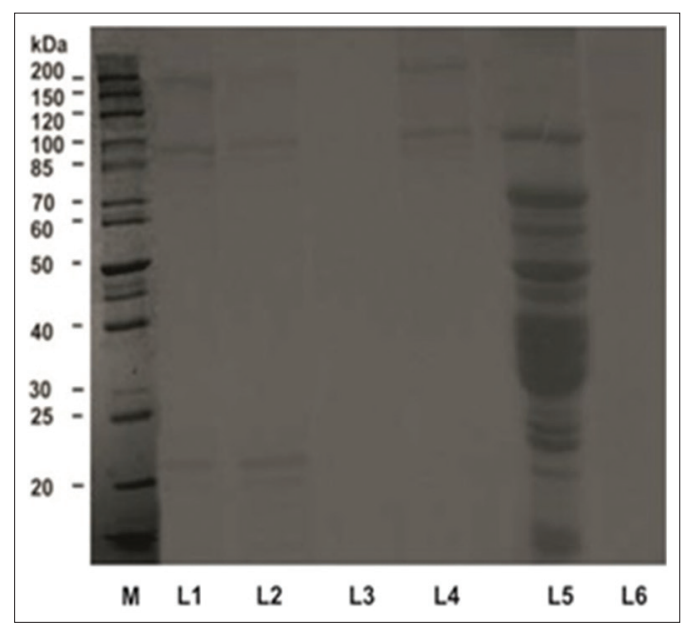

Fig. 6: Sodium dodecyl sulfate polyacrylamide gel electrophoresis pattern of Leiognathus bindus fish protein hydrolysates conditions. Lane $M$ - Wide range standard marker, L1 - Hydrolysate with pH 6, L2 - Hydrolysate with pH 5, L3-Hydrolysate with pH 3, L4- Hydrolysate with pH 4, L5- control sample, L6- Unhydrolyzed sample
Moreover, the amino acid compositions in peptides make a significant biological function [36]. Besides, amino acids such as Arg and His are also establishing biological function like cytotoxic effect. The results shown in Table 2 indicate that protein hydrolysate prepared from L. bindus possess positively charged amino acids in with low molecular weight bioactive peptides. It is notable that a good proportion of His in the total amino acids which might have potential cytotoxicity effect [37].

Inadition, due to the simplicity of the operation and no enzyme costs involved the process is still used for the preparation of protein hydrolysate. The nutritive value of the protein hydrolysate was evaluated through the chemical score, which can be used to compare the levels of EAAs in standard protein and sample. In the present experiment, chemical scores are computed based the reference of FAO/WHO [18] for adults and amino acid requirements especially of the EAAs represent a high proportion among the total $[38,39]$.

The amino acid composition of protein hydrolysate in this study revealed that the hydrolysate contains higher EAA compared to the suggested pattern by FAO/WHO for the adult humans requirements. This is an interesting novel work focus on the nutritional composition, especially the composition in EAAs is a determining factor in human and animal feeding. From this study, it is evident that protein hydrolysate from $L$. bindus can potentially serve as a good source of desirable peptides and EAAs thus it can be used as a functional ingredients food industry.

\section{CONCLUSION}

The outcome of this study shows the potential usage of wasted fish resource for the production of FPH through novel and efficient technology. FPHs obtained from waste fish consist of EAAs and functionally active compounds, which can serve as a potential source for nutritional and pharmaceutical applications. Moreover, this approach offers a relatively simple and cost-effective process in the conversion of waste material. Fish hydrolysate can also serve as another beneficial protein nutritional supplement which can bring economic advantages for the food industry. As the protein hydrolysates prepared in the present study consist of all EAA recommended by FAO/WHO for the adult humans, hence it can serve as a substitute to intact protein in dietary formulations to sustain the nutritional requirements for few populations.

\section{ACKNOWLEDGMENT}

This work is supported by the Department of Science and Technology (DST) and we express our sincere thanks for the financial support under grant by DST.

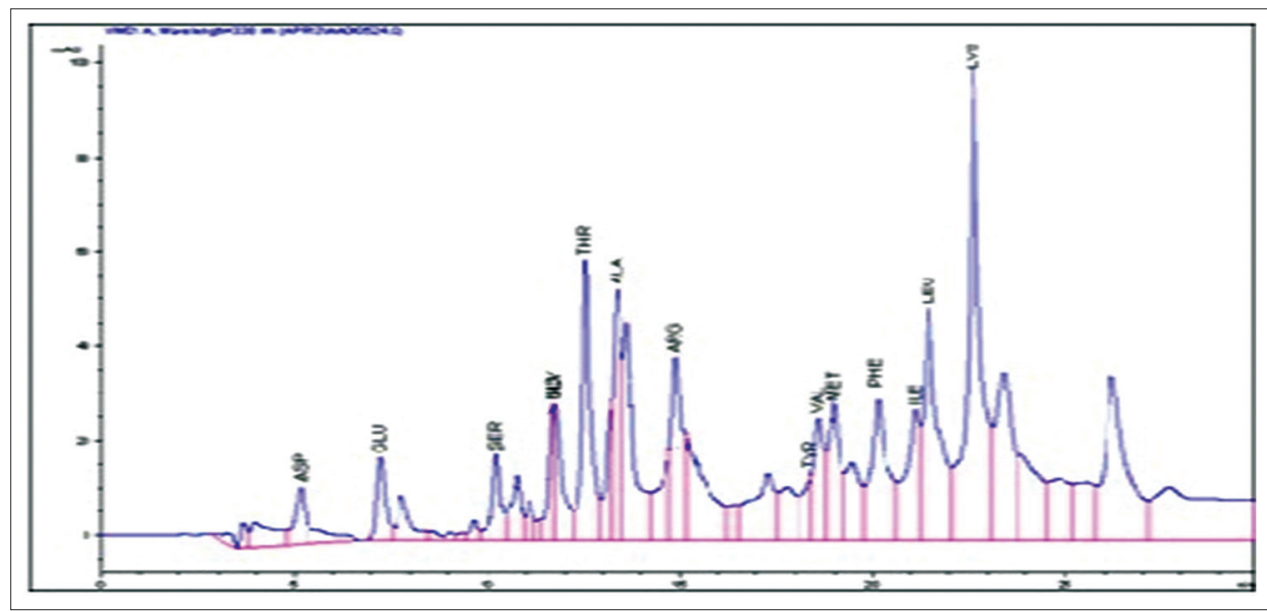

Fig. 7: High-performance liquid chromatography of amino acid composition in fish protein hydrolysates 
Table 2: Comparison amino acid composition and chemical score in FPH (g/100 g) with FAO/WHO and NRC reference protein

\begin{tabular}{|c|c|c|c|c|c|}
\hline \multirow[t]{2}{*}{ Amino acid } & \multirow[t]{2}{*}{ FPH } & \multirow{2}{*}{$\frac{\text { RP1 }}{\text { (Adult) }^{\mathrm{a}}}$} & \multirow{2}{*}{$\begin{array}{l}\text { RP2 } \\
\text { (Poultry) }^{b}\end{array}$} & \multicolumn{2}{|c|}{ Chemical score } \\
\hline & & & & RP1 & RP2 \\
\hline Arginine & 1.22 & & 0.7 & & 1.74 \\
\hline Threonine & 1.91 & 0.9 & 0.47 & 2.1 & 4.06 \\
\hline Tyrosine & 0.32 & - & - & - & - \\
\hline Valine & 1.83 & 1.3 & 0.7 & 1.4 & 2.61 \\
\hline Methionine & 1.81 & 1.7 & 0.3 & 1.06 & 6.03 \\
\hline Phenylalanine & 2.22 & 3.8 & $0.83^{c}$ & 0.58 & 2.67 \\
\hline Isoleucine & 1.78 & 1.3 & 0.65 & 1.33 & 2.06 \\
\hline Leucine & 2.37 & 1.9 & 0.82 & 1.24 & 2.89 \\
\hline Lysine & 2.99 & 1.6 & 0.69 & 1.86 & 4.33 \\
\hline Histidine & 1.92 & 1.6 & 0.17 & 1.2 & 11.29 \\
\hline Alanine & 1.21 & & & & \\
\hline Aspartic acid & 0.72 & & & & \\
\hline Glutamic acid & 2.14 & & & & \\
\hline Serine & 2.14 & & & & \\
\hline Glycine & 0.98 & & & & \\
\hline
\end{tabular}

RP1: Chemical score calculated with FAO/WHO reference protein as the base. RP2: Chemical score calculated with amino acid requirements as per NRC (1993). aSuggested EAA profile requirements in adults (FAO/WHO, 1990). ${ }^{b} E A A$ requirements for poultry, according to NRC (1993). FPH: Fish protein hydrolysate, EAA: Essential amino acid

\section{REFERENCES}

1. FAO. The State of World Fisheries and Aquaculture. Rome: Food and Agriculture Organization of the United Nations, FAO Fisheries and Aquaculture Department; 2009. p. 176.

2. Davies RW, Cripps SJ, Nickson A, Porter G. Defining and estimating global marine fisheries bycatch. Mar Policy 2009;33:661-72.

3. Funge-Smith S, Lindebo E, Staples D. Asian Fisheries Today; The Production and Use of Low Value/Trash Fish7 From Marine Fisheries in Asia-Pacific Region. Bangkok: Food and Agricultural Organization of United Nations, Regional office Asia and Pacific; 2005. p. 38

4. Murueta JH, Toro MA, Carreno FG. Concentrates of fish protein from bycatch SPS produced by drying processes. Food Chem 2007; 100:705-11

5. Curran V, Casimiro L, Banfield V, Hall P, Lackie K, Simmons B, et al. Research for interprofessional competency-based evaluation (RICE). J Interprof Care 2009;23(3):297-300.

6. Klompong V, Benjakul S, Kantachote D, Shahidi F. Antioxidative activity and functional properties of protein hydrolysate of yellow stripe trevally as influenced by degree of hydrolysis and enzyme type. Food Chem 2007;102(4):1317-27.

7. Hoyle NT, Merritt JH. Quality of fish protein hydrolysates from herring (Clupea harengus). J Food Sci 1994;59(129):76-9.

8. Foh MB, Kamara MT, Amadou I, Wenshui X. Chemical and physicochemical properties of Tilapia (Oreochromis niloticus) fish protein hydrolysate and concentration. Int J Biol Chem 2011;5(1):21-36.

9. Gildberg A. Recovery of proteinases and protein hydrolysates from fish viscera. Bio Technol 1992;39:271-6.

10. Saritha K, Patterson J. Innovative seafood health mix powder juveniles of Leiognathus sp. And their quality for human consumption. World J Dairy Food Sci 2014;9(2):113-20.

11. AOAC. Official Methods of Analysis. $16^{\text {th }}$ ed. Washington, D.C: Association of Official Analytical Chemists; 2002

12. Kunitz M. Crystalline soybean trypsin inhibitor: II. General properties. J Gen Physiol 1947;30(4):291-310.

13. Walter HE. Proteins methods with hemoglobin, casein and azocoll as substrates. In: Bergmeyer HU, editor. Methods of Enzymatic Analysis. Vol. 5. Weinheim: Verlag Chemie; 1984. p. 270-7.

14. Coffman CW, Garcia V. Functional properties and amino acid content of protein isolate form mung bean flour. J Food Technol 1977;12:473-84.

15. BeuchatLR. Functional and electrophoretic characteristic of succinylated peanut flour protein. J Agric Food Chem 1977;25(2):258-61.
16. Laemmli UK. Cleavage of structural proteins during the assembly of the head of bacteriophage T4. Nature 1970;227(5259):680-5.

17. Ovissipour M, Abedian AM, Motamedzadegan A, Rasco B, Safari R, Shahiri $\mathrm{H}$. The effect of enzymatic hydrolysis time and temperature on the properties of protein hydrolysates from the Persian sturgeon viscera. Food Chem 2009;115(1):238-42.

18. FAO/WHO. Protein quality evaluation. Report of the Joint FAO/WHO Expert Consultation. Rome: Food and Agriculture Organization of the United Nations; 1990.

19. NRC. National Research Council Nutrient Requirements of Fish. Washington: National Academy of Sciences; 1993. p. 124.

20. Shahidi F. Extraction and measurement of total lipids. Curr Protoc Food Anal Chem 2001;D1:1.1-11

21. Aspmo SI, Horn SJ, Eijsink VG. Enzymatic hydrolysis of Atlantic cod (Gadus morhua L.) Viscera. Process Biochem 2005;40(5):1957-66.

22. Samaranayaka AG, Kitts DD, Li-Chan EC. Antioxidative and angiotensin-I-converting enzyme inhibitory potential of a Pacific hake (Merluccius productus) fish protein hydrolysate subjected to simulated gastrointestinal digestion and Caco-2 cell permeation. J Agric Food Chem 2010;58(3):1535-42.

23. Kristinsson HG, Rasco BA. Fish protein hydrolysates: Production, biochemical, and functional properties. Crit Rev Food Sci Nutr 2000;40(1):43-81.

24. Bhaskar N, Benila T, Radha C, Lalitha RG. Optimization of enzymatic hydrolysis of visceral waste proteins of Catla (Catla catla) for preparing protein hydrolysate using a commercial protease. Bioresour Techno 2008;99(2):335-43

25. Nemati M, Javadian SR, Ovissipour M, Keshavarz M. A study on the properties of Alosa (Alosa caspia) by-products protein hydrolysates using commercial enzymes. World Appl Sci J 2012;18(7):950-6.

26. Prabha J, Narikimelli A, Sajini MI, Vincent S. Optimization for autolysis assisted production of fish protein hydrolysate from underutilized fish Pellona dicthela. Int J Sci Eng Res 2013;4(11):1863-70.

27. Motamedzadegan A, Davarniam B, Asadi G, Abedian A, Ovissipour M. Optimization of enzymatic hydrolysis of yellowfin tuna Thunnus albacares viscera using neutrase. Int Aquat Res 2010;2(3):173-81.

28. Ovissipour M, Rasco B, Shiroodi SG, Modanlow M, Gholami S, Nemati M. Antioxidant activity of protein hydrolysates from whole anchovy sprat (Clupeonella engrauliformis) prepared using endogenous enzymes and commercial proteases. J Sci Food Agric 2013;93(7):1718-26.

29. Souissi N, Bougatef A, Triki-Ellouz Y, Nasri M. Biochemical and functional properties (Sardinella aurita) byproduct hydrolysate. Food Technol Biotechnol 2007;45(2):187-94.

30. Amiza MA, Kong YL, Faazaz AL. Effects of degree of hydrolysis on physicochemical properties of Cobia (Rachycentron canadum) frame hydrolysate. Int Food Res J 2012;19(1):199-06.

31. Barrett D. From natural products to clinically useful antifungals. Biochim Biophys Acta 2002;1587(2-3):224-33.

32. Chen YQ, Edwards IJ, Kridel SJ, Thornburg T, Berquin IM. Dietary fatgene interactions in cancer. Cancer Metastasis Rev 2007;26(3-4):535-51.

33. Yin H, Pu J, Wan Y, Xiang B, Bechtel PJ, Sathivel S. Rheological and functional properties of catfish skin protein hydrolysates. J Food Sci 2010;75(1):E11-7

34. Foegeding EA, Luck PJ, Davis JP. Factors determining the physical properties of protein foams. Food Hydrocoll 2006;20(2-3):284-92.

35. Samaranayaka AG, Li-Chan EC. Autolysis-assisted production of fish protein hydrolysates with antioxidant properties from Pacific hake (Merluccius productus). Food Chem 2008;107(2):768-76.

36. Song R, Wei RB, Luo HY, Yang ZS. Isolation and identification of an antiproliferative peptide derived from heated products of peptic hydrolysates of half-fin anchovy (Setipinna taty). J Funct Foods 2014;10:104-11.

37. Gashti AB, Prakash HS. Characterization of antioxidant and antiproliferative activities of Indian salmon (Eleutheronema tetradactylum) protein hydrolysates. Int $\mathrm{J}$ Pharm Pharm Sci 2016;8(5):102-8

38. Nesse KO, Nagalakshmi AP, Marimuthu P, Singh M. Efficacy of a fish protein hydrolysate in malnourished children. Indian J Clin Biochem 2011;26(4):360-5

39. Khora SS. Marine fish-derived bioactive peptides and proteins for human therapeutics. Int J Pharm Pharm Sci 2013;5(3):31-7. 